\title{
Composite materials for aerospace applications
}

\author{
P D MANGALGIRI \\ Aeronautical Development Agency, Vimanapura PO, Bangalore 560017 , India
}

\begin{abstract}
Fibre-reinforced polymer composite materials are fast gaining ground as preferred materials for construction of aircraft and spacecraft. In particular, their use as primary structural materials in recent years in several technology-demonstrator front-line aerospace projects world-wide has provided confidence leading to their acceptance as prime materials for aerospace vehicles. This paper gives a review of some of these developments with a discussion of the problems with the present generation composites and prospects for further developments. Although several applications in the aerospace sector are mentioned, the emphasis of the review is on applications of composites as structural materials where they have seen a significant growth in usage. The focus of the paper is especially on the developments on the Indian aerospace scene.

A brief review of composites usage in aerospace sector is first given. The nature of composite materials behaviour and special problems in designing and working with them are then highlighted. The issues discussed relate to the impact damage and damage tolerance in general, environmental degradation and long-term durability. Current solutions are briefly described and the scope for new developments is outlined. In the end, some directions for future work are given.
\end{abstract}

Keywords. Composite materials; aerospace applications.

\section{Introduction}

Emergence of strong and stiff reinforcements like carbon fibre along with advances in polymer research to produce high-performance resins as matrix materials have helped meet the challenges posed by the complex designs of modern aircraft. The large-scale use of advanced composites in current programmes of development of military fighter aircraft, small and big civil transport aircraft, helicopters, satellites, launch vehicles and missiles all around the world is perhaps the most glowing example of the utilization of potential of such composite materials. For the first time, perhaps, polymers are playing a key role as materials of construction of aerospace vehicles and components. The current generation military aircraft have about one-third of the structural weight of the aircraft built in advanced fibre-reinforced polymer composites which includes such critical and primary structures as wing, fin, control surfaces and radome. The proportion is somewhat less (up to $15 \%$ ) and restricted more to secondary structures in large civil transport but the trend is picking up. On the other hand, small all-composite aircraft have been on the anvil for some time. These non-metallic materials are competing favourably with advanced metallic materials such as new and improved alloys of $\mathrm{Al}-\mathrm{Li}, \mathrm{Al}-\mathrm{Cu}, \mathrm{Al}-\mathrm{Zn}$ and $\mathrm{Ti}$. The newness and the unconventional nature of composites have undoubtedly brought in their own peculiarities and complexities in design, analysis and fabrication of aircraft structures. But, the concurrent advances in processing technology coupled with the advanced computational technology and numerical methods have played a key role in overcoming such difficulties and promote the application and growth of composites to aircraft structures. In India, too, current national programmes in aerospace sector place a significant emphasis on use of composite materials. Such programmes include development of advanced fighter, an advanced light helicopter, a small all-composite passenger aircraft, remotely piloted vehicles, satellites and launch vehicles. This paper briefly reviews the use of composites in these programmes, the materials used and the issues of concern with them. Some possible developments in near future are also outlined. Much of the discussion in the paper is based on the experience in the currently on-going development of the Indian Light Combat Aircraft (LCA).

\section{The aerospace structures and features}

Important requirements of an aerospace structure and their effect on the design of the structure are presented in table 1.

Further, the structure has to meet the requirements of fuel sealing and provide access for easy maintenance of equipments. Passenger carriage requires safety standards to be followed and these put special demands of fire-retardance and crash-worthiness on the materials and design used. For space craft the space environment-vacuum, radiation and thermal cycling-has to be considered and specially developed materials are required for durability.

Two key developments in scientific-technological world have had a tremendous influence on the generation and 
satisfaction of the demands raised by the aerospace community: one, the advances in the computational power and the other, the composites technology using fibre reinforced polymeric materials. The complexity of the latter had been tamed by the powerful computational tools as well as CAD modelling and computer interfaces in manufacturing.

\section{Use of composites in aerospace structure}

It is to be realized that in order to meet the demands in table 1 , it is necessary to have materials with a peculiar property-set. The use of composites has been motivated largely by such considerations. The composites-in particular, the advanced fibre reinforced composites using carbon or aramid fibres in polymer matrices-offer several of these features as given below:
- Light-weight due to high specific strength and stiffness;

- Fatigue-resistance and corrosion resistance;

- Capability for high-degree of optimization: tailoring the directional strength and stiffness;

- Capability to mould large complex shapes in small cycle time reducing part count and assembly times. Good for thin-walled or generously curved construction;

- Capability to maintain dimensional and alignment stability in space environment;

- Possibility of low dielectric loss in radar transparency;

- Possibility of achieving low radar cross section.

These composite materials also have some inherent weaknesses:

- Laminated structure with weak interfaces: poor resistance to out-of-plane tensile loads;

- Susceptibility to impact-damage and strong possibility of internal damage going unnoticed;

Table 1. Features of aircraft structure.

\begin{tabular}{|c|c|c|}
\hline Requirement & Applicability & Effect \\
\hline - Light-weight & $\begin{array}{l}\text { All Aerospace } \\
\text { Programmes }\end{array}$ & $\begin{array}{l}\text { Semi-monocoque construction } \\
\text { * Thin-walled-box or stiffened structures } \\
\text { Use of low density materials: } \\
\text { * Wood * Al-alloys * Composites } \\
\text { High strength/weight, High stiffness/weight }\end{array}$ \\
\hline - High reliability & $\begin{array}{l}\text { All Aerospace } \\
\text { Programmes }\end{array}$ & $\begin{array}{l}\text { Strict quality control } \\
\text { Extensive testing for reliable data } \\
\text { Certification: Proof of design }\end{array}$ \\
\hline - Passenger safety & Passenger vehicles & $\begin{array}{l}\text { Use of fire retardant materials } \\
\text { - Extensive testing: Crashworthiness }\end{array}$ \\
\hline $\begin{array}{l}\text { - Durability- } \\
\text { Fatigue and } \\
\text { corrosion } \\
\text { Degradation: } \\
\text { Vacuum } \\
\text { Radiation } \\
\text { Thermal }\end{array}$ & Spacecraft & $\begin{array}{l}\text { Extensive fatigue analysis/testing } \\
\text { * Al-alloys do not have a fatigue limit!!! } \\
\text { Corrosion prevention schemes } \\
\text { - Issues of damage and safe-life, life extension } \\
\text { Extensive testing for required environment } \\
\text { - Thin materials with high integrity }\end{array}$ \\
\hline $\begin{array}{l}\text { - Aerodynamic } \\
\text { performance }\end{array}$ & $\begin{array}{l}\text { Aircraft } \\
\text { Reusable spacecraft }\end{array}$ & $\begin{array}{l}\text { Highly complex loading } \\
\text { Thin flexible wings and control. surfaces } \\
\text { * Deformed shape-Aeroelasticity * Dynamics } \\
\text { Complex contoured shapes } \\
\text { * Manufacturability: N/C Machining; Moulding }\end{array}$ \\
\hline $\begin{array}{l}\text { - Multi-role or } \\
\text { functionality }\end{array}$ & $\begin{array}{l}\text { All Aerospace } \\
\text { Programmes }\end{array}$ & $\begin{array}{l}\text { Efficient design } \\
\text { Use: composites with functional properties }\end{array}$ \\
\hline - Fly-by-wire & $\begin{array}{l}\text { Aircrafts, mostly for } \\
\text { fighters but also } \\
\text { some in passenger a/c }\end{array}$ & $\begin{array}{l}\text { - Structure-Control Interactions } \\
\text { * Aero-servo-elasticity } \\
\text { - Extensive use of computers and electronics } \\
\text { * EMI shielding }\end{array}$ \\
\hline - Stealth & $\begin{array}{l}\text { Specific Military } \\
\text { Aerospace Appl }\end{array}$ & $\begin{array}{l}\text { Specific Surface and Shape of aircraft } \\
\text { * Stealth coatings!!! }\end{array}$ \\
\hline $\begin{array}{l}\text { - All-weather } \\
\text { operation }\end{array}$ & Aircraft & - Lightning protection, erosion resistance \\
\hline
\end{tabular}


- Moisture absorption and consequent degradation of high temperature performance;

- Multiplicity of possible manufacturing defects and variability in material properties.

Even after accepting these weaknesses, the projected benefits are significant and almost all aerospace programmes use significant amount of composites as highlighted in figure 1. All this is, of course, not without its share of hassles. Challenges of using composites on such a large scale are many. The composites are not only new but also non-conventional: they are anisotropic, inhomogeneous, have different fabrication and working methods and also different controls for quality assurance. They have a complex material behaviour under load requiring new and complicated analysis tools. Moreover, the behaviour is not always predictable by analysis and this makes reliance on several expensive and timeconsuming tests unavoidable.
The routes to meet these challenges have evolved around use of the advances in computer technology and analysis methods to implement schemes based on computer aided design, computer aided engineering, finite element methods of analysis and building computer interfaces amongst all aspects of development, namely, design, analysis and manufacturing. These should provide fast transfer of information including graphics and accurate analysis methods for a reasonable prediction of complex behavioural patterns of composites. It is only by harnessing the vast computational power for various purposes that the aircraft structural design of today can meet the challenges posed by the required performance.

\section{Materials for aerospace composites}

The material systems which have been considered useful in aerospace sector are based on reinforcing fibres and

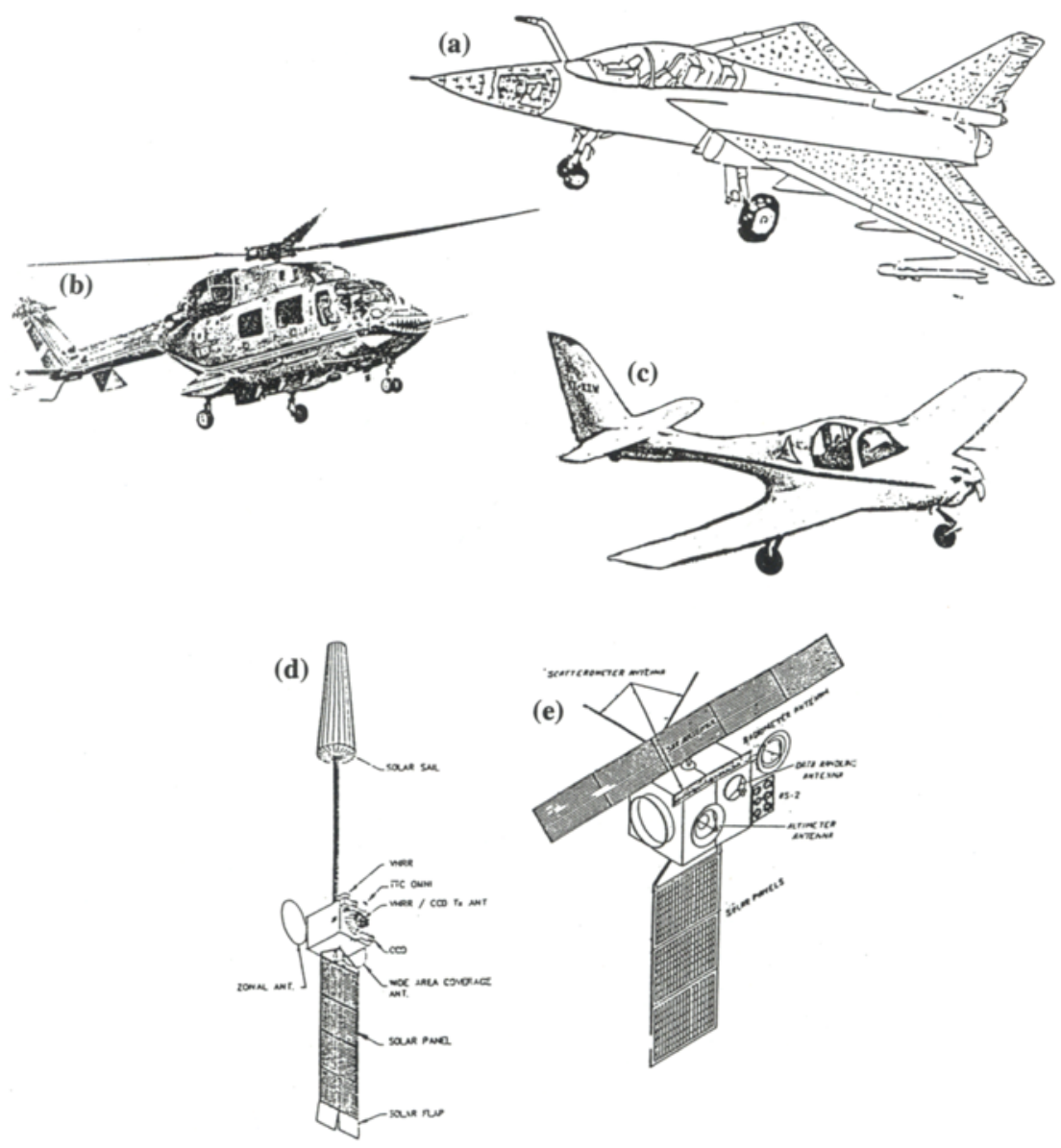

Figure 1. Use of composites in various aerospace programmes: (a) A military aircraft with wings, fin, control surfaces, and fuselage panels made in carbon-epoxy, radome in aramidpolyester. (b) An advanced helicopter using aramid, glass and carbon composites in all structural parts. (c) An all composite 2-seater transport aircraft using glass-epoxy supplemented with carbon. (d) and (e) satellites using carbon composites for solar panels, antennae, etc. 
matrix resins given in tables 2 and 3, respectively. Most aerospace composites use prepregs as raw materials with autoclave moulding as a popular fabrication process. Filament winding is popular with shell like components such as rocket motor casings for launch vehicles and missiles. Oven curing or room temperature curing is used mostly with glass fibre composites used in low speed small aircraft. It is common to use composite tooling where production rates are small or moderate; however, where large number of components are required, metallic conventional tooling is preferred. Resin injection moulding also finds use in special components such as radomes. Some of the popular systems are given in table 4 along with the types of components where they are used in a typical high-performance aircraft.

\section{Concerns with composite usage}

The concern in use of composites arises mainly due to demands of high degree of reliability and safety of aerospace structures as against the complexity of composite behaviour and consequent difficulties in building prediction models. This creates an excessive reliance on testing at all stages: design and development, proving and certification, and in-service inspection and repairs. The costs of such testing are sometimes enormous and this had led to some scepticism in use of composites.
Two major issues in this regard are briefly discussed below.

\subsection{Impact damage and damage tolerance}

The laminated structure of the composites and the fibre-matrix interfaces provide weak interfaces for delamination or debonding to take place. This is further aggravated by practical structural features such as discontinuous plies to create thickness changes and sharp bends required in stiffening members. Of particular concern is the proneness exhibited for damage due to impact. The issue is not merely the reduction in strength (particularly in compression) but also that the damage is inside the material and not visible at the structure. This is particularly so where the impact is due to blunt objects at low to medium velocities. Common instances are dropping of tools, hail-stones, runway debris and impacts and jolts while handling (even before the assembly of the aircraft). Such hidden damage can be extensive-both in terms of planar dimensions and through the thickness. The damage mostly occurs as delamination, but may sometimes be accompanied by fibre-breaks in back plies which are not visible from outside. In the shop, such damages can be found by ultrasonic $\mathrm{C}$-scan method and a 'barely visible impact damage' can cause a reduction in compression strength

Table 2. Reinforcing fibres commonly used in aerospace applications.

\begin{tabular}{|c|c|c|c|c|}
\hline Fibre & $\begin{array}{l}\text { Density } \\
(\mathrm{g} / \mathrm{cc})\end{array}$ & $\begin{array}{l}\text { Modulus } \\
\text { (GPa) }\end{array}$ & $\begin{array}{l}\text { Strength } \\
\text { (GPa) }\end{array}$ & Application areas \\
\hline \multicolumn{5}{|l|}{ Glass } \\
\hline E-glass & $2 \cdot 55$ & $65-75$ & $2 \cdot 2-2 \cdot 6$ & $\begin{array}{l}\text { Small passenger a/c parts, air } \\
\text { craft interiors, secondary parts } \\
\text { Radomes; rocket motor casings }\end{array}$ \\
\hline S-glass & $2 \cdot 47$ & $85-95$ & $4 \cdot 4-4 \cdot 8$ & $\begin{array}{l}\text { Highly loaded parts in small } \\
\text { passenger } a / c\end{array}$ \\
\hline \multicolumn{5}{|l|}{ Aramid } \\
\hline Low modulus & 1.44 & $80-85$ & $2 \cdot 7-2 \cdot 8$ & Fairings; non-load bearing parts \\
\hline $\begin{array}{l}\text { Intermediate } \\
\text { modulus }\end{array}$ & 1.44 & $120-128$ & $2 \cdot 7-2 \cdot 8$ & $\begin{array}{l}\text { Radomes, some structural parts; } \\
\text { rocket motor casings }\end{array}$ \\
\hline High modulus & 1.48 & $160-170$ & $2 \cdot 3-2 \cdot 4$ & Highly loaded parts \\
\hline \multicolumn{5}{|l|}{ Carbon } \\
\hline $\begin{array}{l}\text { Standard modulus } \\
\text { (high strength) }\end{array}$ & $1 \cdot 77-1.80$ & $220-240$ & $3 \cdot 0-3 \cdot 5$ & $\begin{array}{l}\text { Widely used for almost all types } \\
\text { of parts in a/c, satellites, antenna } \\
\text { dishes, missiles, etc }\end{array}$ \\
\hline $\begin{array}{l}\text { Intermediate } \\
\text { modulus }\end{array}$ & $1.77-1.81$ & $270-300$ & $5 \cdot 4-5 \cdot 7$ & $\begin{array}{l}\text { Primary structural parts in high } \\
\text { performance fighters }\end{array}$ \\
\hline High modulus & $1.77-1.80$ & $390-450$ & $\begin{array}{l}2 \cdot 8-3 \cdot 0 \\
4 \cdot 0-4 \cdot 5\end{array}$ & $\begin{array}{l}\text { Space structures, control surfaces } \\
\text { in } a / c\end{array}$ \\
\hline Ultra-high strength & $1.80-1.82$ & $290-310$ & $7.0-7.5$ & $\begin{array}{l}\text { Primary structural parts in high } \\
\text { performance fighters, spacecraft }\end{array}$ \\
\hline
\end{tabular}


by almost $60 \%$. The fatigue resistance of carbon composites stands it in good stead, however, and no further significant reduction in strength or growth of damage is observed under in-plane loads.

The current philosophy to handle impact damage problem is as follows: (i) design the structure to have alternate load paths to have damage tolerance against impact of moderate severity. This is generally taken care by designing the structure as a framework of stiffening members or as boxes; (ii) lower the design allowable strength values to an extent where the 'barely visible impact damage (BVID)' can be sustained even at the highest load and for all the time with no degradation in performance; (iii) any damage that exceeds the BVID level (i.e. visible damage) may lower the immediate performance and should be repaired immediately. The basic safety of aircraft with damage is ensured due to (i) and (iv) the structure may not cater to very severe impact.

There is, of course, a penalty in lowering the allowables but for the present systems, this is considered to be not too excessive in view of the similar reduction of allowables required for fastener holes. With improved processing to get large parts integral with stiffeners and other complex shapes and with availability of high strength fibres the limitations due to impact damage would be more perceptible and prohibitive.

Another consequence of the impact damage issue which the aeronautical community is, perhaps, not yet fully exposed to is in terms of setting up of the inspection intervals and defining levels of repairs etc when the presently developed aircraft go in full service. Extensive studies and gathering of experience through testing is presently underway to tackle this problem.

Table 3. Polymeric matrices commonly used in aerospace sector.

\begin{tabular}{|c|c|c|c|c|}
\hline \multicolumn{4}{|c|}{ Thermosets } & \multirow{3}{*}{$\begin{array}{c}\text { Thermoplastics } \\
\text { No chemical change } \\
\text { PPS, PEEK }\end{array}$} \\
\hline \multicolumn{4}{|c|}{ Forms cross-linked networks in polymerization curing by heating } & \\
\hline Epoxies & Phenolics & Polyester & Polyimides & \\
\hline $\begin{array}{l}\text { - Most popular } \\
\text { - } 80 \% \text { of total composite } \\
\text { usage } \\
\text { - Moderately high temp. } \\
\text { - Comparatively } \\
\text { expensive }\end{array}$ & $\begin{array}{l}\text { - Cheaper } \\
\text { - Lower viscosity } \\
\text { - Easy to use } \\
\text { - High temp usage } \\
\text { - Difficult to get good } \\
\text { quality composites }\end{array}$ & $\begin{array}{l}\text { - Cheap } \\
\text { - Easy to use } \\
\text { - Popular for general } \\
\text { applications at } \\
\text { room temp }\end{array}$ & $\begin{array}{l}\text { - High temp } \\
\text { application } \\
300^{\circ} \mathrm{C} \\
\text { - Difficult to } \\
\text { process } \\
\text { - Brittle }\end{array}$ & $\begin{array}{l}\text { - Good damage } \\
\text { tolerance } \\
\text { - Difficult to process } \\
\text { as high temp } 300-400^{\circ} \mathrm{C} \\
\text { is required }\end{array}$ \\
\hline $\begin{array}{l}\text { - Low shrinkage }(2-3 \%) \text {; } \\
\text { - No release of volatile } \\
\text { during curing }\end{array}$ & $\begin{array}{l}\text { - More shrinkage } \\
\text { - Release of volatile } \\
\text { during curing }\end{array}$ & - High shrinkage (7-8\%) & & \\
\hline $\begin{array}{l}\text { Can be polymerized in } \\
\text { several ways giving } \\
\text { varieties of structures, } \\
\text { morphology and wide } \\
\text { range of properties }\end{array}$ & $\begin{array}{l}\text { - Inherent stability for } \\
\text { thermal oxidation. } \\
\text { - Good fire and flame } \\
\text { retardance } \\
\text { - Brittle than epoxies }\end{array}$ & $\begin{array}{l}\text { - Good chemical } \\
\text { resistance } \\
\text { - Wide range of properties } \\
\text { but lower than epoxies. } \\
\text { - Brittle } \\
\text { - Low } T_{g}\end{array}$ & & \\
\hline $\begin{array}{l}\text { - Good storage stability to } \\
\text { make prepregs }\end{array}$ & $\begin{array}{l}\text { - Less storage stability- } \\
\text { difficult to prepreg }\end{array}$ & - Difficult to prepreg & & $\begin{array}{l}\text { - Infinite storage life. But } \\
\text { difficult to prepreg }\end{array}$ \\
\hline $\begin{array}{l}\text { Absolute moisture } \\
\text { (5-6\%) causing swelling } \\
\text { and degradation of high } \\
\text { temp properties } \\
\text { - Also ultra violet } \\
\text { degradation in long term }\end{array}$ & $\begin{array}{l}\text { - Absorbs moisture but no } \\
\text { significant effect of } \\
\text { moisture in working } \\
\text { service range }\end{array}$ & $\begin{array}{l}\text { - Less sensitive to } \\
\text { moisture than epoxies }\end{array}$ & & - No moisture absorption \\
\hline - Density $\left(\mathrm{g} / \mathrm{cm}^{3}\right)$ & $\begin{array}{l}\text { Density }\left(\mathrm{g} / \mathrm{cm}^{3}\right) \\
1 \cdot 2-1 \cdot 4\end{array}$ & $\begin{array}{l}\text { - Density }\left(\mathrm{g} / \mathrm{cm}^{3}\right) \\
1 \cdot 1-1 \cdot 4\end{array}$ & & - Density $\left(\mathrm{g} / \mathrm{cm}^{3}\right) \quad 1 \cdot 3-1 \cdot 4$ \\
\hline $\begin{array}{l}\text { - Tensile modulus } \\
2 \cdot 7-5 \cdot 5 \mathrm{GPa}\end{array}$ & $\begin{array}{l}\text { - Tensile modulus } \\
2.7-4 \cdot 1 \mathrm{GPa}\end{array}$ & $\begin{array}{l}\text { - Tensile modulus } \\
1 \cdot 3-4 \cdot 1 \mathrm{GPa}\end{array}$ & & $\begin{array}{l}\text { - Tensile modulus } \\
3.5-4.4 \mathrm{GPa}\end{array}$ \\
\hline $\begin{array}{l}\text { - Tensile strength } \\
40-85 \mathrm{MPa}\end{array}$ & $\begin{array}{l}\text { - Tensile strength } \\
35-60 \mathrm{MPa}\end{array}$ & $\begin{array}{l}\text { - Tensile strength } \\
40-85 \mathrm{MPa}\end{array}$ & & $\begin{array}{l}\text { - Tensile strength } \\
100 \mathrm{MPa}\end{array}$ \\
\hline
\end{tabular}


There is also a problem of bullet impact on composite components especially those carrying aircraft fuel. Apart from the damage to composite, there is an apprehension that the pressure wave due to such an impact will cause a hydraulic ram effect in the fuel which will compress the air-fuel mixture in the space in the tank and lead to explosion.

\subsection{Environmental degradation}

The presently used epoxy resins absorb about 5-6\% moisture by weight when fully saturated. This leads to about $1.5-1.8 \%$ moisture weight gain in carbon-epoxy composites with the usual $60 \%$ fibre volume fraction. In practice, under the normal operating conditions, the maximum equilibrium moisture gain in an aircraft component can be about $1.0-1.4 \%$. This moisture gain can cause (a) swelling and dimensional changes, (b) lowering of the glass transition temperature $\left(T_{\mathrm{g}}\right)$ of the resin matrix, and (c) degradation of matrix dominated properties of composites such as shear and compression strengths.

The dimensional changes and weight gain by itself are generally not significant in many aircraft structures but may be of considerable significance where extreme precision is required such as in antennae panels and in some satellite structures. The major concern in aircraft structures is the degradation of the shear and compressive strength properties-particularly at high temperatures close to $T_{\mathrm{g}}$ which in itself is now reduced due to moisture absorption. The design of a structural component, there- fore, generally proceeds by reducing allowables for moisture degradation. This in itself is rather straightforward. More complicated problems, however, arise in getting the proof of design and the certification of airworthiness. It is generally prohibitively expensive and often impractical to test actual components in the environmentally worst conditions to demonstrate adequate strength under those conditions and recourse has to be taken to extrapolation from data obtained from coupons and smaller structures. Such extrapolations are not always straightforward and extensive test programmes are required to demonstrate proof of design. A typical approach taken is the 'building-block approach' of generating data on various levels of increasing complexity. Table 5 illustrates a typical test programme for a major aircraft component like a wing. Note the decrease in number of specimens as the complexity of the specimen geometry increases.

This single issue of environmental degradation due to moisture absorption has made development of composite components for aerospace quite expensive and tedious. Moreover, associated with the already complex behaviour of composites, the environmental degradation issue leaves some lingering doubts about behaviour of composites, particularly in long term.

Apart from the moisture absorption, the other significant aspects relate to the UV degradation and radiation effects in long term. These are particularly important for space structures. The current studies on the subject have provided some solutions to these problems even though the concern about long term behaviour exists.

Table 4. Typical composite material systems in aerospace.

\begin{tabular}{|c|c|}
\hline Material system & Application area \\
\hline $\begin{array}{l}175^{\circ} \mathrm{C} \text { curing high strength-carbon-epoxy } \\
- \text { Zero-bleed (neat resin content) UD prepregs } \\
\text { - } 5 \mathrm{HS} \text { or } 8 \mathrm{HS} \text { bi-directional fabric prepreg } \\
- \text { toughness, good out-life and shelf-life } \\
175^{\circ} \mathrm{C} \text { curing intermediate modulus carbon } \\
\text { with epoxy }+\mathrm{BMI} / \text { cynate-ester } \\
\text { - Zero-bleed (neat resin content) UD prepregs } \\
\text { - 5HS or } 8 \mathrm{HS} \text { bi-directional fabric prepreg } \\
\text { - high toughness, good out-life and shelf-life } \\
\text { - low environmental degradation }\end{array}$ & $\begin{array}{l}\text { Structural components of fighter aircraft and } \\
\text { helicopters. e.g. wing skins, spars, fin, rudder, } \\
\text { elevons, doors, etc. } \\
\text { Frames, stiffeners, rotor blades }\end{array}$ \\
\hline $\begin{array}{l}120^{\circ} \mathrm{C} \text { curing HS-carbon-epoxy } \\
\text { - Zero-bleed (neat resin content) UD prepregs } \\
\text { - 5HS or } 8 \mathrm{HS} \text { bi-directional fabric prepreg } \\
\text { - toughness, good out-life and shelf-life }\end{array}$ & $\begin{array}{l}\text { Structural components of helicopters or transport } \\
\text { aircraft. e.g. spars, fin, rudder, elevons, doors, } \\
\text { etc. } \\
\text { Frames, stiffeners }\end{array}$ \\
\hline - Aramid fibre in low-loss polyester/cynate esters & Radome \\
\hline - Cu-mesh epoxy prepreg & For Lightning Strike protection Wing-skin, others \\
\hline $\begin{array}{l}\text { E-glass fabric in epoxy resins } \\
\text { - High temp curing } \\
\text { - RT/moderate temp curing }\end{array}$ & $\begin{array}{l}\text { Fighters fairings, fin-radome, drop-tanks } \\
\text { Small transport aircraft structural compo- } \\
\text { nents : : Fuselage, wing, other }\end{array}$ \\
\hline
\end{tabular}




\section{Advances in materials for composites}

\subsection{Reinforcements}

The carbon fibre technology continues to improve harnessing the versatility of carbon fibre and new varieties in terms of better combinations of modulus and strength are becoming available. The developments seem to be in two directions: one, for aircraft applications, is aimed basically at higher strength $(>5 \mathrm{GPa})$ with concurrent improvements in modulus to a moderate level (>300 GPa) and the other, for space applications, is aimed at high modulus (>500 GPa) with moderate strength $(\sim 3.5 \mathrm{GPa})$. The higher failure strain for the fibre is expected to result in composites with better damage tolerance. The developments in aramid fibres also aim at higher modulus with concurrent increase in strength. However, the major thrust in improving reinforcements for composites comes from the requirements of multidirectional weaving. Several processes (weaving, knitting, braiding) have been developed for this purpose and preforms with multidirectionally woven fibres have now been made. Simplification and cost reductions appear to be the major motives for further developments.

The higher properties of basic fibres (such as carbon) cannot, however, be fully exploited in the composite without concurrent developments in the matrix materials and the intermediate products such as prepregs or preforms. It is to be noted here that the carbon fibre composites which use a carbon fibre with a strength of $3 \mathrm{GPa}$ as reinforcement result in an allowable stress of only $0.3 \mathrm{GPa}$ in a composite. Significant scope thus exists for translating high fibre properties into high performance of composites.

\subsection{Matrix resins}

A significant effort in improving composites is focused on improving matrix materials. The two major concerns mentioned earlier viz. impact damage tolerance and hygrothermal degradation, provide the main motivation for improvement. A major direction of improvement appears to be an improvement in the toughness which should result in higher resistance to delamination and against impact. High failure strain of matrix resin would help in translating the higher performance of the improved fibre to the composite. Higher resin shear modulus would help in achieving better transfer of load from fibre to resin and again to fibre and should therefore improve compression strength. For polymeric materials a possible figure of $\sim 5 \mathrm{GPa}$ should be achievable as against the current resins with shear modulus of about $2 \mathrm{GPa}$. As far as hygrothermal degradation is considered, newer systems based on cynate ester look very promising and some of these have already found some application. Another route being investigated is the use of thermoplastic resins and their blends. Poly-ether-ether-ketone (PEEK) has been considered very promising, but the industry needs to resolve the problems associated with high temperature $\left(>350^{\circ} \mathrm{C}\right)$ processing of the material. Current approaches to new resins appear to be directed towards producing polymeric systems which can be processed in the way composites industry is used to (such as autoclave curing up to $180^{\circ} \mathrm{C}$ ). Two promising classes of materials under development are given below.

(i) Polymerizable liquid crystalline monomers: These should result in thermoset resins with high fracture toughness and $T_{\mathrm{g}} \approx 170^{\circ} \mathrm{C}$ with high retention $(\approx 90 \%)$

Table 5. A typical approach for design validation (example: composite wing).

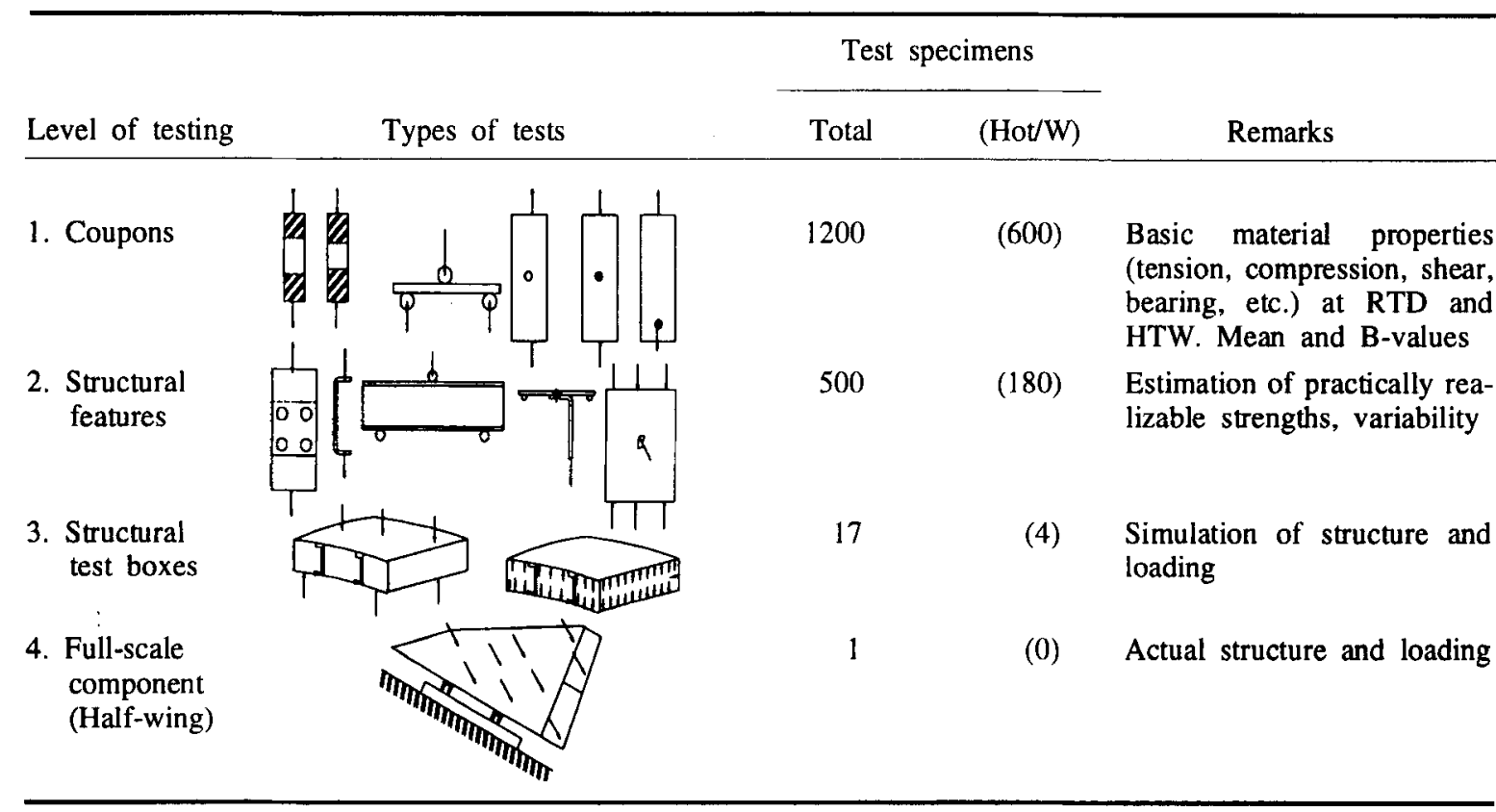


under hot-wet conditions. Comparing to thermoplastic PEEK, such resins will have almost similar fracture toughness (composite $G_{\mathrm{lc}} \approx 800 \mathrm{~J} / \mathrm{m}^{2}$ ) with the advantage of conventional processing. The system is being looked into for potential applications in civil transport aircraft. The approach for development of these new resins that is being followed is first, to synthesise controlled molecular weight backbones consisting of aromatic ethers, aromatic esters or rigid aliculic systems with hydroxy end groups and then to end-cap these backbones with reactive end groups like cynate ester group or glycidyl ethers.

(ii) Phthalonitrile resins for high temperature applications which can be cured in conventional manner (at 180$200^{\circ} \mathrm{C}$ ) but can be post-cured, albeit in inert atmosphere, at high temperatures up to $600^{\circ} \mathrm{C}$. Compared with the presently available PMR resins for high temperature $\left(250-350^{\circ} \mathrm{C}\right)$ applications, the new resins will have better processibility, good fracture resistance, better strength and modulus and very low moisture absorption.

The other area of advances in resins is that of low-loss resins specially for radomes which use high-performance advanced radars. Varieties of low-loss polyesters and cynate esters are being explored.

\section{Future}

The use of composite materials for several aerospace components in current programmes worldwide has resulted in considerable weight savings estimated to be about $30 \%$. The technologies developed and the confidence gained have paved the way for further spread of composites to more complicated components in aerospace, such as in fuselages of aircraft, to gain further weight savings. This involves, of course, some new challenges: the fuselage has several cutouts, deeply contoured curved parts, out-of-plane loadings and load-transfer through bulkheads. The current trend is to use co-curing and co-bonding processes to produce integral components which will avoid use of fasteners altogether. Such constructions when used for pressurized tanks or other areas of tri-axial stress put the weakest link of resin in the direct flow of load and this poses a new challenge for designers. Apart from the development of tougher resins and highstrain fibres mentioned above, the growth of composites as aircraft structural materials will depend upon the success of cost reduction techniques which is now becoming the focus of attention for new developments. Towards this end, we are likely to see development of convenient (easy-to-use) intermediate products and new process technologies which will improve the damage tolerance and hygrothermal performance as well as produce parts at a lower cost. Some of these developments can be mentioned as stitched hybrids, development of new process technologies such as resin transfer moulding (RTM) and resin infusion moulding (RIM) to replace expensive and slow autoclave moulding of prepregs, development of multidirectional preforms, development of grid structures and Z-reinforcements.

One of the new areas of significant importance to aerospace sector is the use of 'smart' materials and structures. The concept of designing the passive structure to also perform some other useful functions-becoming smart-is already proven in laboratories using fibre optics and piezo-electric sensors and actuators. Composites are best suited for such applications. Main applications that are being pursued are structural health monitoring, vibration and noise control, aerodynamic flow manipulation through surface modification, smart actuation of control surfaces. Use of such techniques will provide additional safety measures and improved performance and will overcome some of the limitations of composite due to their complexity.

The future aerospace composite structures can therefore be expected to be highly optimized and smart. The service experience gained on already flying structures and the advances in materials and process technologies and in computer techniques will increase the confidence in these complex structures and make designing with them an affordable exercise-affordable without impracticable testing.

\section{Acknowledgements}

The paper has been compiled on the basis of information contained in several presentations of the Indian Aerospace. Programmes in various National conferences. In particular, thanks are due to Shri M K Sridhar, Dr R M V G K Rao, Dr B K Parida and Shri S Seetharam, National Aerospace Laboratories, Bangalore and to Dr P S Nair, ISRO Satellite Centre, Bangalore for their help. 